\title{
Forage shrubs for the South Island dry hill country: 1. A triplex halimus L. (Mediterranean saltbush)
}

\author{
B.J. WILLS,' J.S.C. BEGG,' and M. BROSNAN ${ }^{2}$ \\ ' DSIR, P.O. Box 228, Alexandra \\ 2 Riverside, Hakataramea, RD Kurow
}

\begin{abstract}
As an essential ingredient in the development of the South Island's dry hill country, shrubs have a vital role in the amelioration of extreme climatic effects, gully erosion control and in the provision of stock forage. Trials have been conducted in the South Island over the past 20 years, culminating in the establishment of farm scale plantings of Atriplex halimus (Mediterranean saltbush) on "Riverside" (Mike Brosnan), Hakataramea, in 1985. Some $20+$ ha of saltbush "forage banks" now exist on this property. The selection of Atriplex species adapted to the dry, cold hill country in the South Island is briefly described together with establishment and grazing management techniques appropriate to farm scale plantings of forage banks. These have been developed on exposed, sunny faces which, in the past, were low priority areas for pastoral development. The climatic adaptability, the--preferred- soil types and nutrient status, the management and the conservation values of Atriplex halimus as a forage plant are discussed. This is directed at stimulating further integration of forage banks into farming systems appropriate to semi-arid conditions. Planting normally unproductive dryland site with forage shrubs, in combination with other drought tolerant pasture plants, is seen as an important step in the development of successful farming strategy suited to these environments. The positive and practical results realised to date at Riverside need to be developed on other South Island dryland properties as a means of expanding shrub forage bank plantings over a wider range of climate and soil types in New Zealand.
\end{abstract}

Keywords Atriplex halimus, Mediterranean saltbush, forage banks, nutrition, grazing and economic analyses, semi-arid climate

\section{Introduction}

The initial emphasis for the shrub evaluation programme, started in the early 1970 s by the then Plant Materials Centre, MOWD, was based on national concerns for soil conservation and erosion control. A network of on-farm trial sites was established throughout the country, in conjunction with this programme, into which a wide range of plants was introduced.

Atriplex species were among the earliest to be planted and these were placed at several sites in Otago, Manawatu, Marlborough and the East Coast (North Is). Later introductions and evaluation included numerous accessions of the following species:

A triplex: atacamensis, brewerii, cana, canescens*, confertifolia, coquimbensis, cuneata, halimoides, halimus*, hortensis, lentiformis, leucoclada, muelleri, nummularia *, nuttallii, obovata, polycarpa, pseudocampanulata, repanda, robusta, semibaccata*, stipitata, tridentata, vesicaria.

$*$ = internationally researched species of which a wide range of provenances were-evaluated in-NZ-(see-Methods):

Of these introductions, only a few were found to be well adapted to conditions in New Zealand. A. brewerii, canescens, halimus, nummularia and semibaccata all showed promise but many were adversely affected by unseasonal frosting or exhibited poor growth form. A. halimus was the only species to Wnd general acceptance for trial, and later large scale, planting.

Because of the obvious association of saltbush with saline soils, much of the early work concentrated on sites with this characteristic. Specific problem areas such as tunnel gullied and coastal soils were studied. It was not until the 1980s (Wills 1984) that real interest was shown in the forage value of Atriplex in New Zealand. A. halimus is commonly exploited for such use in its Mediterranean homeland, and to a lesser extent in Africa, USA and Australia where $A$. nummularia and $A$. canescens are also frequently used.

Good performance of Mediterranean saltbush in the field plus the evident acceptability of it to stock prompted evaluation for farm scale plantings and a 
closer look at the nutritional value of the plant under New Zealand conditions. A. nummularia and $\boldsymbol{A}$. canescens have shown only limited success here, mainly because of their susceptibility to unseasonal frost and/or their moderate vigour.

\section{Methods}

The results discussed are based on randomised, replicated plantings made at a number of South Island sites since 1972 involving several hundred plants of each species. While not all accessions of each species were evaluated at every site, the following are the numbers of accessions held for the most important species: $A$. canescens $=26 ; A$. numularia $=6 ;$ A. halimus $=6 ;$ A. semibaccata $=11$.

Plant vigour (0-5 scale), plant height, spread and annual growth $(\mathrm{mm})$, phenology, disease and other environmental damage effects were assessed biannually for the plantings. At most sites, a minimum of 25 plants per accession as 5 replicates were planted annually, beginning in 1972. Severa different sites and accessions per species were planted each year, and at larger sites numbers of plants established per accession per year often exceeded 250.

Soil analysis results are based on MAF Quicktest standards. Plant mineral analyses were carried out by the Southland Co-op Phosphate Co Ltd (Invercargill) and the in vitro digestibility analyses were provided by the Animal and Veterinary Sciences Group, Lincoln College. These analyses were based on randomly collected samples for each species-site which were then dried at $<40^{\circ} \mathrm{C}$ and ground to provide individual sample weights of at least $200 \mathrm{~g}$ for digestibility testing and $100 \mathrm{~g}$ for minerals testing. For the digestibility study, the parameters given are (D. Poppi, pers. comm.): Metabolic energy = Dry matter digestibility x $15.7 / 100=\mathrm{MJME} / \mathrm{Kg} \mathrm{DM}$

$\%$ Ether extract $=$ Lipid fraction of the plant

$\%$ Neutral detergent fibre $=$ Cell wall fraction of the plant.

\section{Plant descriptions}

As discussed in the introduction, plant selection trials established that, of the 20 or so saltbush species (and 100 odd accessions) tested since 1972, A. halimus was the most tolerant of local climatic conditions and exhibited superior performance at many sites. The information that follows thus refers to A. halimus unless other species are specifically referred to.

A. halimus is a medium sized, rounded shrub which, in New Zealand, typically grows to about 2.0 $\mathrm{m}$ height and, if not browsed, will spread to similar dimensions. The leaves (about $40 \times 30 \mathrm{~mm}$ ) are silvery grey-green, ovate-deltoid in shape and have prominent midribs, the lower surface being speckled with numerous excretory glands which help maintain the plant's osmotic balance. Flowers are borne on terminal panicles with the earlier flowering male glomerules superior to the female bracteoles. Flowering occurs in late summer and seed ripens in mid-late autumn. Annual growth in the first season from planting may exceed $1.0 \mathrm{~m}$ on good sites, but after that it reduces to about $0.25-0.30 \mathrm{~m}$ per year. The leaves, which are quite palatable, are usually retained during winter although very cold temperatures $(>-18$ "C) may cause some leaf loss.

A. nummufaria is similar in form but much more erect (c. $2.5 \times 0.5 \mathrm{~m})$. Accessions evaluated to date have proved to be intolerant of severe winter frosts and early spring frosts exceeding about $-10^{\circ} \mathrm{C}$, although acceptability of foliage to stock is good. $A$. canescens is small statured (to $0.5 \mathrm{~m}$ height), has narrow strap-like leaves and prominent, four-winged seeds (see PM Handbook 1986). The main constraints with its use are slow growth, mediocre establishment and low palatability.

\section{Plant establishment and performance}

Early results indicated that Mediterranean saltbush could not be successfully established from openrooted or hardwood cuttings. Propagation from freshly collected and dried seed or by containerised cuttings grown from heeled, one-season-old wood, is recommended. Direct-drilling trials have been carried out but with limited success. The seed strike after drilling is widely reported as being erratic (Nord et al. 1971; IFRES 1984) and the New Zealand situation is little different. However, naturalised seedlings do occur in some circumstances, notably on sandyloamy soils with minimal vegetation-litter cover. This has happened at Olrig, Chatto Ck and, in 1989, at Riverside downwind from 1-year-old shrubs.

For on-farm establishment, containerised plants at a density of 500 (about $5 \times 5 \mathrm{~m}$ spacing) to 1500 (about $1.5 \times 4 \mathrm{~m}$ spacing) per hectare will provide a comprehensive "forage bank". Adequate space should be left between rows to facilitate stock movement, but plants within a row may be closely spaced as in a hedge. Competing vegetation must be reduced to a minimum by stock or non-residual chemical means to enhance establishment and early performance. Old lucerne areas should be sprayed out before planting with saltbush. Stock should be excluded until seedlings are well established.

Dryland pasture plants (e.g. sheep's burnet, birdfoot trefoil, chicory, prairie grass, wheatgrass) may be broadcast or sown between the shrubs to increase the productivity of these "forage banks" and to provide a more comprehensive ground cover. It should be emphasised that many of these pasture plants do not carry bulk greenfeed through the winter, or for that matter into severe drought conditions, as well as does saltbush.

Plant performance has been best on soils of a saline nature (e.g. Chapman and Manorburn browngrey earth-BGE-soils) and those with high base saturation levels, often overlying calcareous parent rock (e.g. Wetherburn and Otematata BGE soils in 
Table 2 Atriplex Herbage Mineral Analysis -1990

\begin{tabular}{|c|c|c|c|c|c|c|c|c|c|c|c|c|c|c|c|}
\hline Site/Sample & $\mathrm{Ca}^{*}$ & $\mathrm{~K}$ & $\mathrm{P}$ & $\mathrm{Mg}$ & $\mathrm{Na}$ & $\mathrm{S}$ & $\mathrm{N}$ & $\mathrm{Si}$ & $\mathrm{Cl}$ & $\mathrm{Fet}$ & $\mathrm{Mn}$ & $\mathrm{Zn}$ & $\mathrm{Cu}$ & B & Al \\
\hline $\begin{array}{l}\text { A. halimus } \\
\text { - Nursery } \\
\text { - Olrig } \\
\text {. Bendigo } \\
\text { - Riverside } \\
\end{array}$ & $\begin{array}{l}1.30 \\
\mathbf{0 . 8 0} \\
1.10 \\
1.00 \\
\end{array}$ & $\begin{array}{l}6.50 \\
\mathbf{2 . 7 0} \\
3.50 \\
4.20 \\
\end{array}$ & $\begin{array}{l}0.20 \\
\mathbf{0 . 2 0} \\
0.10 \\
0.20 \\
\end{array}$ & $\begin{array}{l}0.90 \\
1.00 \\
1.60 \\
1.30 \\
\end{array}$ & $\begin{array}{l}2.90 \\
5.40 \\
6.60 \\
3.80 \\
\end{array}$ & $\begin{array}{c}0.40 \\
0.50 \\
0.50 \\
0.50 \\
\end{array}$ & $\begin{array}{l}3.50 \\
3.20 \\
1.20 \\
2.50 \\
\end{array}$ & $\begin{array}{l}0.10 \\
0.40 \\
0.10 \\
0.10 \\
\end{array}$ & $\begin{array}{l}1.70 \\
6.40 \\
9.40 \\
4.60 \\
\end{array}$ & $\begin{array}{l}151 \\
\mathbf{4 3 9} \\
201 \\
148 \\
\end{array}$ & $\begin{array}{r}90 \\
106 \\
74 \\
54 \\
\end{array}$ & $\begin{array}{l}25 \\
\mathbf{5 0} \\
13 \\
33 \\
\end{array}$ & $\begin{array}{c}22 \\
16 \\
23 \\
12 \\
\end{array}$ & $\begin{array}{l}\text { NR } \\
\text { NR } \\
24 \\
14 \\
\end{array}$ & $\begin{array}{l}\mathbf{2 7 4} \\
818 \\
\mathbf{4 9 2} \\
120\end{array}$ \\
\hline $\begin{array}{l}\text { A. nummul. } \\
\text { - Bendigo } \\
\text { - Riverside } \\
\end{array}$ & $\begin{array}{l}1.00 \\
1.20 \\
\end{array}$ & $\begin{array}{l}2.80 \\
5.10 \\
\end{array}$ & $\begin{array}{l}0.10 \\
0.30 \\
\end{array}$ & $\begin{array}{l}0.70 \\
0.90 \\
\end{array}$ & $\begin{array}{l}5.10 \\
2.50 \\
\end{array}$ & $\begin{array}{l}0.60 \\
0.30 \\
\end{array}$ & $\begin{array}{l}1.00 \\
2.70 \\
\end{array}$ & $\begin{array}{l}0.10 \\
0.10 \\
\end{array}$ & $\begin{array}{l}5.20 \\
2.90 \\
\end{array}$ & $\begin{array}{l}213 \\
240 \\
\end{array}$ & $\begin{array}{r}130 \\
59 \\
\end{array}$ & $\begin{array}{l}22 \\
47 \\
\end{array}$ & $\begin{array}{r}13 \\
9 \\
\end{array}$ & $\begin{array}{l}36 \\
19 \\
\end{array}$ & $\begin{array}{l}336 \\
240 \\
\end{array}$ \\
\hline $\begin{array}{l}\text { M. saliva } \\
\text {. Bendigo } \\
\text { D. glomer }\end{array}$ & 2. 10 & 1. 20 & 0.10 & 0.40 & 0.10 & 0.20 & 3.50 & 0.80 & 0.20 & 1048 & 58 & 18 & 14 & $\mathrm{NR}$ & 1537 \\
\hline $\begin{array}{l}\text { - Bendigo } \\
\text { S. minor } \\
\text { - Bendigo }\end{array}$ & 0.90 & 0.90 & $\begin{array}{l}0.10 \\
0.40 \\
\end{array}$ & 0.40 & 0.50 & 0.10 & NR & 0.60 & 0.80 & 585 & 71 & $\begin{array}{l}12 \\
23 \\
\end{array}$ & $\begin{array}{l}11 \\
14 \\
\end{array}$ & NR & 1665 \\
\hline
\end{tabular}

* Major elements as \% of DM

+ Trace Elements as PPM of DM

$\mathrm{NR}=\mathrm{No}$ Record

also be utilised during mid-summer droughts providing plants are given plenty of time to recover before winter and that grazing is limited to 1 (possibly 2) period(s) per year. Adequate subdivision will allow use of different forage bank areas at both times of year where necessary.

To date no disease problems have been noted with any Atriplex species. There have been recent occurrences of a stem-boring caterpillar which is having a mildly debilitating effect on a recently introduced (previously untried) South African line of A. nummularia, cv 'de Kock', now commercially planted en masse at several sites with the support of the Rural Bank. The effect on A. halimus appears to be minimal. Leaf-roller caterpillar can be a problem on young plants in some seasons.

\section{Plant nutrient status}

Because of the current interest shown in the feed value of shrubs such as saltbush when planted as forage banks, a better understanding of the plant mineral and digestibility levels is required. This information has been obtained for plants growing at three sites on widely differing soil types: Olrig (solonetzic), Bendigo (typical dryland BGE) and Riverside (BGE overlying limestone). Results for the mineral analysis are presented in Table 2, together with those of some traditional pasture plants for comparison.

The levels of $\mathrm{K}, \mathrm{Mg}, \mathrm{Na}, \mathrm{Cl}$ and $\mathrm{Mn}$ in saltbush are high compared with those of lucerne and cocksfoot. The $\mathrm{Al}$ level is considerably lower and that of most other minerals is of a similar level.

The results for the in vitro digestibility analysis are presented in Table 3. Atriplex spp. show a lower protein level than lucerne or willow. Fibre levels are, as expected highest for the tree willow. Metabolic energy levels for all saltbush samples are about $20 \%$ higher than lucerne or willow, as are dry matter digestibility levels. Field observations have shown that, particularly with Merino sheep, fresh $\boldsymbol{A}$. halimus foliage is highly sought after in spring (and is preferred to green lucerne) and, as the above information indicates, the herbage supplies good quality forage with a high nutrient status.

Table 3 Atriplex Herbage Digestibility Analysis - 1990

\begin{tabular}{|c|c|c|c|c|c|c|c|c|}
\hline Site/Sample & $\begin{array}{c}\% \\
\text { Protein } \\
\end{array}$ & $\begin{array}{l}\% \text { Ether } \\
\text { Extract }\end{array}$ & $\begin{array}{c}\% \\
\text { Ash }\end{array}$ & $\begin{array}{l}\% \text { CR } \\
\text { Fibre }\end{array}$ & $\begin{array}{c}\% \\
\text { NDF } \\
\end{array}$ & $\begin{array}{c}\% \\
\mathrm{DMD}\end{array}$ & $\begin{array}{c}\% \text { Sol } \\
\text { Carboh. }\end{array}$ & $\mathrm{ME}$ \\
\hline $\begin{array}{ll}\text { A. } & \text { halimus } \\
\text { Olrig } \\
\text { - Bendigo } \\
\text {. Riverside } \\
\end{array}$ & $\begin{array}{l}2.31 \\
3.04 \\
3.06 \\
\end{array}$ & $\begin{array}{l}1.97 \\
1.85 \\
1.95 \\
\end{array}$ & $\begin{array}{l}28.48 \\
34.47 \\
25.59\end{array}$ & $\begin{array}{l}8.45 \\
7.55 \\
1.76\end{array}$ & $\begin{array}{l}30.65 \\
27.60 \\
28.51\end{array}$ & $\begin{array}{l}78.15 \\
80.42 \\
79.83\end{array}$ & $\begin{array}{l}58.79 \\
53.09 \\
61.64\end{array}$ & $\begin{array}{l}\mathbf{1 1 .} 85 \\
\mathbf{1 2} .19 \\
12.11\end{array}$ \\
\hline $\begin{array}{l}\text { A. nummularia } \\
\text { - Bendigo } \\
\text { - Riverside } \\
\end{array}$ & $\begin{array}{l}1.76 \\
3.53 \\
\end{array}$ & $\begin{array}{l}1.93 \\
1.93 \\
\end{array}$ & $\begin{array}{l}28.63 \\
22.20 \\
\end{array}$ & $\begin{array}{l}7.97 \\
1.56 \\
\end{array}$ & $\begin{array}{l}29.55 \\
27.46 \\
\end{array}$ & $\begin{array}{l}81.72 \\
79.57 \\
\end{array}$ & $\begin{array}{l}59.71 \\
64.78 \\
\end{array}$ & $\begin{array}{l}12.39 \\
12.07 \\
\end{array}$ \\
\hline $\begin{array}{l}\text { M. sativa - ex Lincoln } \\
\text { D. glomerata : ex Lincoln } \\
\text { S. matsudana } \text { ex OCB }\end{array}$ & $\begin{array}{c}18.00 \\
\mathbf{0 . 9 0} \\
0.50\end{array}$ & $\begin{array}{l}2.50 \\
\text { NR } \\
2.33\end{array}$ & $\begin{array}{r}\mathbf{9 .} \mathbf{6 0} \\
10.00 \\
\mathbf{1 0 . 7 0}\end{array}$ & $\begin{array}{l}23.00 \\
\text { NR } \\
16.49\end{array}$ & $\begin{array}{l}52.50 \\
45.00 \\
32.43\end{array}$ & $\begin{array}{l}64.57 \\
78.00 \\
60.47\end{array}$ & $\begin{array}{l}48.00 \\
55.00 \\
57.17\end{array}$ & $\begin{array}{r}9.80 \\
12.24 \\
9.17\end{array}$ \\
\hline
\end{tabular}

$\mathrm{DMD}=$ dry matter digestibility $\quad \mathrm{NR}=$ No Record 


\section{The farmer experience}

Concern about the lack of cover on Riverside's sunny faces, both for environmental and economic reasons; prompted a search for any information which might rectify this situation. In addition to conservation values, a perennial crop was required to provide a feed bank for winter or drought feed. Other considerations included water harvesting, building up soil organic matter, shelter for stock at lambing, and the provision of a habitat for wildlife, including pest predators (especially those of rabbits), from erosion-susceptible sunny faces which produced little under traditional management techniques.

The trail led to DSIR, Alexandra and their dryland research work with browsing shrubs and grasses. In 1985, among many other prospective browsing plants, six A. 3alimu.s seedlings were planted on a sunny face. This was the beginning of a programme on Riverside termed. "sunny face treatment". Saltbush was included as just one part of a total land use planning programme on Riverside, tied into the broad principles of conversation and organic farming.

The topography of Riverside lends itself to "land use fencing". The property consists of flat-top terraces and valley floors with long, steep south and north faces.

The south faces were fenced off in earlier years and development now concentrates on fencing the remaining dry, barren north faces and establishing a cover of browse shrubs and dryland grasses on them. At this stage, the Waitaki Catchment Commission decided to support the programme as a one-off, 50\% - subsidised demonstration.

Despite concerns about the site specificity of $A$. halimus, the initial six plants performed quite well. In 1986, 5 hectares were fenced off and planted with 2000 saltbushes. This was very much a learning year and a lot of mistakes were made, since large-scale farmer planting was quite new at that time in New Zealand. Despite a low (25\%) establishment rate, we were undaunted.

The success year (in retrospect) was 1987. Our technique was as follows:

1. Fenced off 7 hectares involving 3 blocks.

2. Plants were contract grown in paper pots by a good nurseryman.

3. Deep ripped along the contours at $5 \mathrm{~m}$ centres in the autumn.

4. Spot sprayed along ripped lines at $5 \mathrm{~m}$ centres with glyphosate in August.

5. Hand planted 3000 saltbushes in September.

Survival was high but in 1988 planting was missed to give the programme time to prove its worth. The 1986 block was browsed off in August 1988 by $\mathbf{2 5 0 0}$ Merino ewes, just after shearing, pre-lambing. Those hungry, shorn sheep got 1 week's feeding of this block with very little of anything else.
All the 1986 and 1987 blocks (12 ha) were browsed off in August/September 1989, providing 3 weeks' maintenance for 2500 ewes. Because of the success of the programme so. far, another 10 hectares were fenced into 2 blocks and planted with 4000 saltbushes.

At present all the remaining sunny faces on Riverside are being fenced off, involving another 80 hectares of land. The planting programme will continue in spring 1990 . We also intend applying some organically acceptable fertiliser, together with a mixture of dryland pasture plant seed, to the earlier established blocks. Sheep will be used to trample this $\mathrm{m}$.

An economic analysis of the benefits of planting Atriplex on the sunny faces at Riverside has been completed (L. Reid, Canterbury Regional Council, pers. comm.). Calculated on a daily feed cost/ewe of $19 \mathrm{c}$ (silage equivalent to $1.3 \mathrm{~kg} / \mathrm{animal}$ ), a $\mathrm{Net}$ Present Value (10\%) of $\$ 10221$ is achieved over 10 years. This equates to an Internal Rate of Return on investment of $40 \%$ over that period. It is estimated that, on this property, each hectare will provide an additional 3 grazing days/year (at $900 \mathrm{su} / \mathrm{ha}$ ) after 5 years.

\section{Conclusions}

Saltbush, in particular, A. halimus, can provide a useful, nutritious source of feed when grown in forage banks on sunny faces which traditionally produce little feed for stock and are normally susceptible to erosion. Fencing these areas off has also prevented unnecessary transfer of nutrients (with sheep camping) from adjacent, fertile, flats. It would- appear; from- -preliminary data; -that the economics of such forage bank establishment are sound and that management of saltbush planting should not be particularly difficult. The saltbush plantings are an excellent tool for circumventing the adverse effects of drought conditions, especially if they can be combined with other dryland pasture plants, and they also have a valuable conservation role in areas affected by semi-arid climate conditions

\section{REFERENCES}

IFRES, 1984. Proceedings - Symposium on the Biology of Atriplex and Related Chenopods. Provo, May, 1983. In USDA Forest Service, Intermountain Forest and Range Experiment Station, Ogden, UT. General Technical Report INT 172: 309 pp

Nord, C.E.; Hartless, P.; Nettleton, W. 1971. Effects of several factors on saltbush establishment in California. Journal of Range Management 24: 216-223.

PM Handbook, 1986. Plant Materials Handbook for Soil Conservation. Van Kraayenoord, C.W.S and Hathaway, R.L. (Eds). Water and Soil Miscellaneous Publication No. 93,94, Vol 1,2.

Wills, B.J. 1984. Alternative plant species for revegetation and soil conservation in the tussock grassland of New Zealand. Tussock Grasslands and Mountain Lands Institute, Review 42: 49-58 